\title{
Radical Democracy - An Anarchist Perspective
}

\author{
Wayne Price ${ }^{1}$
}

This is an examination of democracy from the perspective of anarchism. The democratic tradition has divided into bourgeois representative democracy and the revolutionary program of direct democracy. While existing democratic freedoms should be defended, the bourgeois-democratic state should be opposed as really serving the interests of capitalism and oppression. Direct democracy is the basis of a future stateless society. The social anarchism of Bakunin and Kropotkin sees humans as social individuals, unique but integrated into a social matrix. It is meaningless to counterpose individual freedom to democracy. While some anarchists reject the term "democracy," the view presented here is that anarchism is democracy without the state. [Article copies available for a fee from The Transformative Studies Institute.E-mail address: journal@transformativestudies.org Website: http://www.transformativestudies.org @2020 by The Transformative Studies Institute. All rights reserved.]

KEYWORDS: Representative Democracy, Direct Democracy, Radical Democracy, Anarchism, Libertarian Socialism.

\section{PART I: DIRECT DEMOCRACY VS. BOURGEOIS- REPRESENTATIVE DEMOCRACY}

Examining democracy from the perspective of anarchism leads in two directions. One is the study of limited "representative" democracy which is the ideological rationale of the existing U.S. capitalist state. The other is "direct" (or "participatory" or "radical") democracy. These may be considered "democracy-from-above" versus "democracy-from-below."

In direct democracy (democracy-from-below) the people themselves make collective decisions in face-to-face meetings. This goes back tens

\footnotetext{
${ }^{1}$ Wayne Price is a long-time activist, writer, and theorist who has been involved in the U.S. revolutionary libertarian Left through a series of organizations. He has worked on peace, union, human rights, and ecological issues. He has been a school teacher and a psychologist. Writing regularly for anarchist journals and for www.Anarkismo.net, he has published books on anarchism and Marxism. Address correspondence to: Wayne Price, email: drwdprice@aol.com.
} 